\title{
The Real Estate Trust in the Building Sector in Colombia
}

\author{
Monroy Vargas ER ${ }^{1 *}$ and Barón Hernández CY2 \\ ${ }^{1}$ Universidad Piloto de Colombia, Colombia \\ 2Universidad Santo Tomás, Colombia
}

*Corresponding author: Edgar Ricardo Monroy Vargas, Universidad Piloto de, CLL

\section{Review Article \\ Volume 1 Issue 2}

Received Date: September 08, 2017

Published Date: October 05, 2017

DOI: $10.23880 /$ jenr-16000111

19 No.11-64, Colombia, Tel: +573102996053; E-mail: edgar-monroy1@unipiloto.edu.co

\section{Abstract}

The construction sector, although it has a private character, is intimately related to the public sector in terms of the normative instruments for the development of the proper activities of construction of buildings. In recent years, the country has experienced significant economic growth, and construction companies have gone to real estate schemes with legal regulation in Colombia, which is insufficient for the development of the sector, causing problems for both builders and consumers, without training and sufficient information for decision making.

Thus, the current legal regulation in Colombia of the real estate scheme FIDIS or International figure of fiduciary law, widely allows the reception of funds and clearly carries a series of risks for the consumer.

Keywords: Raising Money; Patrimony; Economy; Fiduciary schemes; Safe Housing Projects

\section{Introduction}

Construction is one of the main sectors of exponential growth at the national level and in the last 4 years it has increased its value added by $28 \%$, twice the national average, and in the fourth quarter of $2015,6.8 \%$ doubled the growth of the economy in this period and in February 2016, the sector generated on average 61 thousand direct jobs and 122 thousand in real estate activities, contributing $42 \%$ of the new jobs generated in the country [1].
Given this growth, the specifically real estate construction sector has turned to real estate schemes that are not limited to a few investors, but thousands of people attend the business; ergo, it was possible to understand that this financing aimed at the general public for the purpose of raising money could have the legal treatment contemplated in law 964 of 2005 and complementary provisions; and even more so, if FIDIS meet the requirements to be classified as a value ${ }^{1}$, that is, a right of a negotiable nature (in this case by assignment) that forms part of an issue, when it has the purpose or effect of attracting resources.

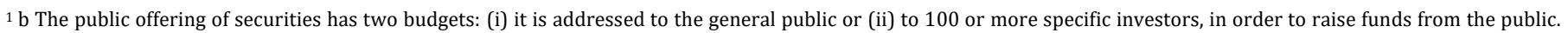

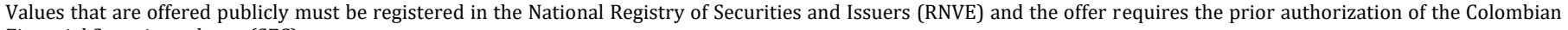
Financial Superintendency (SFC).
} 


\section{Journal of Ecology \& Natural Resources}

Note that because of the effects of the autonomous patrimony and the principle of patrimonial separation established in the national law, the fiduciary as spokesperson only responds in principle with charge and until the concurrence of the funds deposited in the trust, so that, if no yields are generated nor the expected profits are obtained, the fiduciary is not in obligation to inject from its budget the missing money to fulfill the expectation of the business, since the holder of the fiduciary right contained in the FIDIS "International Figure of Real Estate Fiduciary Law" practically becomes investor, transferring the contingencies of loss.

Clearly, the difference that emerges from the scheme of public offering of securities the current FIDIS is that the duty of information contemplated in law 1328 of 2009 and the Basic Legal Circular C.E. 007 issued by the Superintendent of Finance of Colombia, becomes superlative, and in that sense, the demand of the financial institution is the duty of advice, whose rigor is much deeper than mere information.

Notwithstanding the foregoing, the Colombian Financial Superintendence for formal or interpretative reasons has not recognized FIDIS as a value; the consequence of this absence of State intervention is that the ordinary citizen, who does not have knowledge of the rules of the economy, is not able to commit his resources because he does not have enough information or the necessary elements to decide whether it is appropriate their interests or not, investment in these fiduciary schemes.

In addition, fiduciary companies are not required to document or certify that they provided sufficient advice and information to the potential client prior to their relationship; so many of these construction projects are protected by the naivety of the public and the passivity of state control, which in the end has legitimized a practice by the construction companies of crowdfunding real estate, leaving aside the risks of the weak of the business relationship, where the non-professional investor who lacks the tools to give full consent to the obligations assumed in this class of legal structures.

\section{Methodology}

This bibliographic review took as an initial reference the current state of legal management of national fiducias, and the analysis of the new FIDIS scheme managed by Colombian construction companies, as the current real estate figure for the administration of resources of large projects in the country, was consulted in the same way the jurisprudence of the Supreme Court of Justice, Arbitral Awards, circulars of the Financial Superintendence, databases and specialized bibliography to conceptually base and establish the legal effects of contractual civil liability of fiduciary societies and construction companies in the FIDIS figure as a new real estate strategy for construction projects in Colombia.

\section{Development of the Topic}

\section{The Real Estate Trust in Colombia}

The fiducia in Colombia originates from the adoption of the Civil Code, in which articulation was developed fiduciary property, as a limitation to the domain, subject to the fulfillment of a condition to be transferred to another person

The commercial fiduciary business as such, is born infused in the American figure of the trust, applied by the banks like managers of interests of third parties. In this way, it is through Law 51 of 1918 that fiduciary operations are authorized to the Banks, later regulated by Law 45 of 1923, authorizing the Banks to establish the fiduciary section.

Its boom dates back to the 1990s when the builders used mercantile trust as a strategy after the crisis, to reduce the risks associated with construction, since they could start the sale of the work prior to construction [2] and thus ensure the project break-even point, resulting in the accumulation of housing inventories, generating a drop in the prices of the root farm.

Real estate trust funds have since been used as an instrument that guarantees faith and trust between the parties for the development of a construction project and the administration of resources for this purpose; but due to the lack of regulations for the use of this tool, there have been legal disadvantages with the builders and end users, which are attributed to the lack of clarity of some of the fiduciary entities.

This fiduciary instrument has been in the last decades an important ally for the development of construction projects, with different purposes among which are the Fiducia of Administration and Payments, Treasury and Preventas; however, there is no specific regulation, different from that generally defined for the commercialization of real estate projects through the financial system, as well as for the collection of resources and disposal of real estate. 


\section{Journal of Ecology \& Natural Resources}

\section{The Construction and Fiducy Sector}

The construction sector in Colombia has a high impact on the economy, registering a significant increase of its GDP. In the third quarter of 2016, GDP at constant prices grew $1.2 \%$ in relation to the same quarter of 2015 . When analyzing the result of value added by large branches of activity, there is growth in the value added of the construction sector of $5,8 \%$. This result is explained by the $11 \%$ increase in the building sub-sector and an increase of $1.9 \%$ in the civil works subsector $[1,3]$.

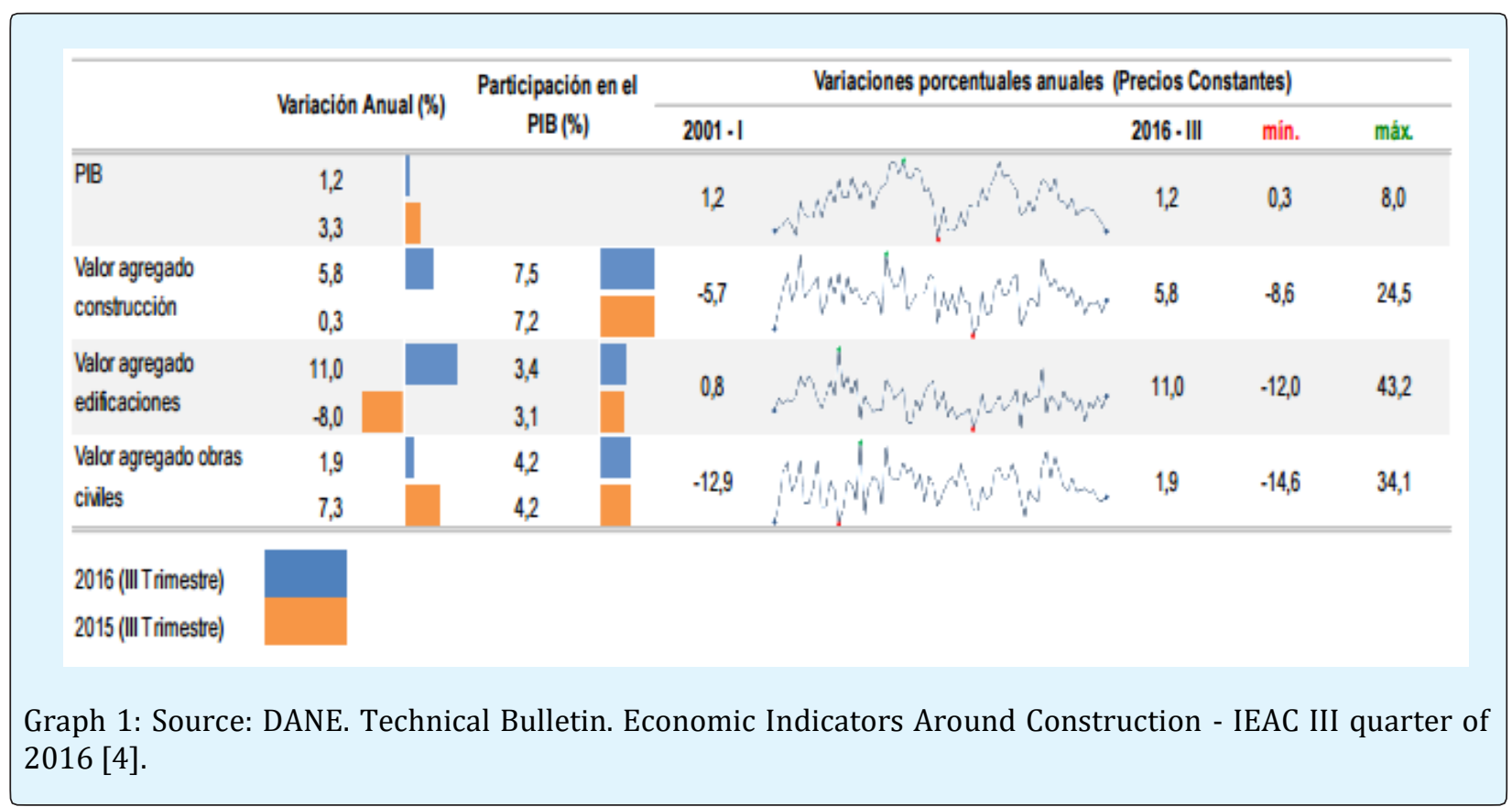

According to the above, the great responsibility assumed by the different actors (construction companies, fiduciary entities) [5] involved in the construction is not less, more when it falls on their entities and agencies the development of real estate projects leading to the improvement of conditions of people's lives, guided by a model promoted by government planning agencies for the stable and orderly growth of the territories. It is then the commitment on the part of the public and private entities that intervene in this vision of the city, to offer the country an offer that fulfills the territorial purposes of the country.

In recent years, in the development of these activities, there has been a need to improve legal security, so the Colombian Chamber of Construction states in its management report that between 2015 and 2016 a dynamic movement is characterized normative, mainly in subjects related to Safe Housing Projects, Horizontal Property, Housing Programs, and Fiduciary Rights; in the latter, the Financial Superintendency intends to regulate the operations carried out through fiduciary rights in order to achieve greater objectivity in the development of business through this route and to establish some general guidelines that allow to safeguard the interests of those involved in matters of Fiducia Contracts and Administration of collective assets with the purpose of marketing fiduciary shares, this proposal being the subject of study by the Superintendency [6].

However, due to this lack of regulations, it is relevant to question the guarantees and prebends that protect the builder in the exercise of his work, through the Fiducias Mercantiles Inmobiliarias; as an essential legal tool for the development of projects of all types and sizes. Likewise, the responsibility that the fiduciary entities for the projects and the pertinent and effective administration of the money destined for this purpose. However, since there is a regulatory framework that regulates this exercise, there are still legislative gaps regarding the responsibility of entities that exercise as resource managers and their scope in the actual mercantile exercise, presenting disadvantages for both builders and end users [6].

In the mechanism of the Fiducia Mercantil, the transferred goods leave the patrimony of the settlor and constitute an autonomous patrimony to fulfill the purpose contemplated in the contract. Goods can not be prosecuted or seized by the creditors of the settlor, except 


\section{Journal of Ecology \& Natural Resources}

when the conditions established to exercise the action of article 1238 of the Commercial Code are met [7]. Autonomous heritage as a contractual and procedural subject may be subject to rights and obligations, its spokesman is the fiduciary society and can acquire the quality of contractor or contractor with their rights and obligations, independently of the trustor and fiduciary.

In Colombia, the development of the fiduciary business is the result of a regulatory process that is not very peaceful and full of contrasts. For example, in the Colombian legislative tradition it is found that the earliest antecedents of fiducia contained in Laws 51 of 1918, and 45 of 1923 by which the Banks were authorized to exercise trust orders through the fiduciary sections (Anglo-Saxon conception derived from the trust), does not keep any relation of consonance with the conception later established in the Code of Commerce issued in 1971 [7].

On this last normative reference, developed in articles 1226 to 1244 of Code Commerce [6] it is noticed as to the object of mercantile trust, which is no longer a typical trust business like its predecessor, but, it responds to a (in spite of invoking the professionalism of the fiduciary) and malleable by the particular interests of the parties involved in the business (trustor, fiduciary and, in some cases, the beneficiary).

Unfortunately, this accumulation of factors and commercial use have given rise to controversial scenarios that lead to questioning the real scope of the trust as a contract, and in addition to that, what responsibility fiduciary societies have towards consumers financiers, builders and the state, who have been affected by the structuring of schemes that ignore the guidelines of the national legal system.

\section{Discussion and Results}

It is worth reflecting as a main point the legal implications of the investment model known as "FIDIS" (international figure of real estate trust law), through which, the construction companies obtain the financing of a real estate project using a autonomous patrimony, where the fiduciary as spokesperson of the same is the one in charge of receiving the resources of the public and administer them independently by means of their investment in a collective portfolio and according to the terms of the fiducia contract [8].

The notion of "FIDIS", popularized in various real estate projects, actually contains several elements that require a more rigorous analysis, including the consideration and risks associated with this practice, the reasons that lead the general public to put their capital in this kind of fiduciary business and the scheme of operation endorsed by the government - need to demand a public offering of securities [8].

In relation to the first point, it is worth clarifying that by being linked to a FIDIS scheme, the investor does not receive for himself any title of independent or tangible property of the building where the urban project is advanced, since the consideration given in reality is an aliquot of real estate, whose profitability will depend on the exploitation of the same and its valuation.

In that vein, a person who invests his resources through FIDIS is not buying any real estate, he is simply leveraging a project of the builder financially and participating in the quality of investor of the same in exchange for a future profitability. This means that, as project investors, citizens who acquire fiduciary rights in this modality are also responsible for losses or contingencies that may arise, including those resulting from the low or null return reported by the collective investment funds managed by the fiduciary society.

Under this understanding, the business landscape presents a risk for citizens, which leads to the following point, that is, the reasons why people come massively to put their savings and assets within these figures whose level of exposure is variable and subject to the circumstances of the constructor.

A key factor for such public decisions is the fact that FIDIS are being offered through a scheme administered and supported through a fiduciary society, ie a professional entity (main feature of the reform of the commercial code and law 45/90) supervised by the Financial Superintendence of Colombia, which "guarantees" the people the transparency of the investment of their resources and the development of the real estate operation.

Certainly, investor confidence in our country as a subjective factor linked to the institutionality and support offered by a society monitored by state oversight and control bodies. That is why, a common element in the publicity of all FIDIS real estate schemes, is the continuous and prominent allusion to the intermediation of fiduciaries as resource managers, a strategy that has worked and has made citizens invest with greater security and in increasing proportions its capital in FIDIS projects. 
However, the institutionality and the name of the trustee is NOT a guarantee of the return of resources invested nor of the returns that are usually promised to the investors in the capitalization phase; as the trustee is limited only to receive contributions, to manage in their collective portfolios and to make the resources available to the builder when the break-even point is reached [9].

Thus, if the business is so open for receipt of funds and clearly involves a series of risks on which the financial consumer is not aware, we question ourselves on why the national government did not demand that the structuring of these businesses be under the scheme of a public offering of securities.

Accordingly, the fiduciary business in Colombia is segmented to the benefit of some individuals who take advantage of the State's inaction, also supported by the indemnity statements of the fiduciary who, by way of convention, exonerates himself from all civil liability against the claims of potential affected with the execution of the same.

\section{References}

1. Camacol (2016) Boletín técnico Indicadores Económicos Alrededor de la Construcción - IEAC III trimestre de.
2. Rodríguez Azuero S (1997) La Responsabilidad del Fiduciario. Bogotá D.C., Colombia: Ediciones Rosaristas.

3. Camacol (2008) Oficina Asesora Jurídica Concepto Jurídico 48 de. Reglamentación Preventa.

4. Graph 1: National Administrative Department of Statistics. (2016) Technical Bulletin. Economic Indicators Around Construction - IEAC III quarter, Bogotá, Colombia.

5. Circular Externa (2016) Superintendencia Financiera de Colombia.

6. Hernández Limongi MP (2011) Guía Jurídica de los Negocios Fiduciarios en Colombia, 1 ${ }^{\text {st }}$ (Edn.), Bogotá D.C., Colombia: Legis.

7. Decreto № 410 (1971) Código del Comercio Colombiano. Diario oficial 33.339, Bogotá, Colombia.

8. Arrubla Paucar J (2007) Abuso de la posición dominante contractual, en regulación financiera, bursátil y derechos del consumidor, Medellín, Colombia: Biblioteca Jurídica Dike.

9. Ley № 1480. Estatuto del Consumidor. Diario oficial 48220, Bogotá, Colombia, del 12 de octubre de 2011.

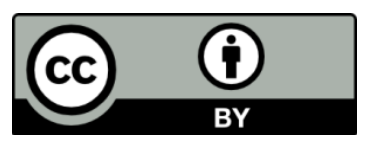

